\title{
Divine Command and Socratic Piety in the Euthyphro
}

\section{GLEN KOEHN/London, Canada/}

While Socrates was in his own way a deeply religious man, his reasoning in the Euthyphro is sometimes thought to weaken the case for a morality based on religious principles. The dialogue famously offers materials for a refutation of the divine command theory of morals: the theory that to say something is morally good is just to say that it is divinely commanded or approved. Socrates suggests that what is pious (tò ö $\sigma ı v$ ) is indeed pleasing to the gods, but it is not pious because it pleases them. Moreover, he goes on to question whether piety can consist in an exchange with the gods, e.g. a trading of worship and obedience for divine favor. Thus, one might be tempted to interpret the dialogue as showing that what is morally good and bad must be independent of the divine will, or even that any consideration about the gods is fundamentally irrelevant to what is morally good and bad.

However, it would be wrong to draw from the Euthyphro the conclusion that religious premises can have nothing to do with the determination of what is good and bad. The dialogue's argument does not show that the criteria for moral goodness must be completely independent of divine preferences. Nor does it show that Socrates himself thought this, though I will argue that Socrates presents Euthyphro with a misleading dilemma when he asks "Is the pious loved by the gods because it is pious, or is it pious because it is loved by the gods?" (Euthphr. 10 a 1-3). There is some complexity here that goes unmentioned. For, in ' $\mathrm{x}$ is loved because $\mathrm{y}$ ' the $\mathrm{y}$ factor could either be a motive for love or it could be some other causal or explanatory factor. Moreover, when the relation- 
ship between goodness and being loved by the gods is better understood we will see that the alternatives 'good because it is loved' and 'loved because it is good' are not mutually exclusive. Hence too the alternatives 'good only because it is loved' and 'loved only because it is good' are not exhaustive. I shall return to these points, which are not just relevant to religious debates but have some wider implications for morality and human preferences.

\section{Some Problems of Piety}

Front and centre in the Euthyphro is the moral virtue picked out by the Greek noun phrase tò öбı $v$, an expression often translated into English as 'piety'. ${ }^{1}$ In the dialogue's dramatic setting the importance of tò öбıv is clear, given that Socrates has recently been indicted for acting disrespectfully towards the gods and for causing others to do the same (Euthphr. $3 \mathrm{a}-\mathrm{b}, 5 \mathrm{a}-\mathrm{b})$. Establishing the nature and object of genuine piety is a pressing task for someone in his circumstances. Socrates is in an awkward position here because, as he hints in the course of his conversation with the prophet Euthyphro, he actually does disbelieve many of the traditional stories passed on by Greek poets about the gods (Euthphr. 6 a). He is therefore in fact guilty as charged of introducing religious novelties relative to some common Athenian conceptions of divinity, and stressing these innovations to the crowd would certainly not help his case. But for Plato writing after Socrates' execution, a persuasive defense of Socratic views about piety - showing that it was Socrates and not his accusers who had sincere respect for what is genuinely sacred - would be a posthumous vindication of his teacher.

The Euthyphro thus invites us to consider, both on behalf of Socrates and ourselves, how best to understand piety and its role in an excellent life. This consideration raises a number of philosophical questions. One obstacle is best disposed of right away: there is a common use of the English words 'piety' and 'pious' which suggests an ostentatious devotion. The words can indicate a holier-than-thou attitude such that most people, even if they are devoutly religious, would feel uncomfortable to hear themselves described as 'pious'. For this reason, it can sound odd to describe Socrates himself as 'a pious man', though Plato clearly intends us to see him as an exemplar of 'to hosion'. Let us set this disparaging usage aside and hold to the claim that to call someone 'pious' is to praise him or her for a form of moral excellence.

More importantly, there is a structure to piety which bears on the argument of the Euthyphro, for the virtue of piety requires due reverence or respect directed towards some object worthy of that attitude. One cannot be pious without being pious towards something or someone to whom one owes a certain deference. Filial piety, for example,

\footnotetext{
${ }^{1}$ Harold North Fowler in the Loeb edition renders the expression as 'holiness' (Cambridge, MA, Harvard University Press; London, William Heinemann Ltd. 1966). This translation is not entirely suitable, for reasons which I hope will become obvious.
} 
is a sufficiency of respect towards parents by their children. ${ }^{2}$ While there is no expression in the dialogue corresponding to the English phrase 'filial piety', and the point is not entirely explicit because piety is stressed mainly in regard to the gods rather than parents (e.g. at Euthphr. 8 b, 15 d), the prophet Euthyphro is presented by Plato as someone who lacks just this excellence of due respect to a parent. Socrates expresses astonishment at Euthyphro's behavior, and it is surely a deliberate Platonic irony that a son prosecuting his own father provides the occasion for the whole discussion.

Besides the honor due to parents, the appropriate respect demanded by piety may be directed to a god, to a benefactor such as a teacher, or to some other thing with elevated status, such as truth. ${ }^{3}$ The idea that this respect is something that is owed suggests that to withhold it would actually be unjust, an idea which shows up in Socrates' subsequent observation that piety is a part of justice (Euthphr. $12 \mathrm{~d}$ ). The directedness of piety means that when we consider a pious act there is more than one thing under discussion. First, there is the sufficiently respectful action itself, which being an instance of moral excellence is an instance of goodness more generally. On Plato's account the pious action

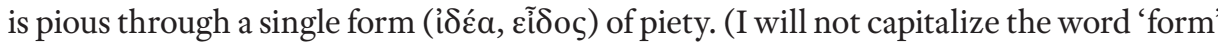
here, simply because it is not clear just how fully developed Plato's theory of transcendent Forms is in the Euthyphro.) Then there is also that object towards which the appropriately respectful person directs his or her respect, an object which must be of such a sort and relation to us as to deserve a reverent attitude.

Hence our inventory of what piety entails must include at least the following:

1. The pious actions. These respectful deeds and attitudes will exemplify

2. The virtue of piety. Plato takes this to be a shared form (Euthphr. $5 \mathrm{~d}, 6 \mathrm{~d}$ ). Then there is

3. The object of the respectful actions. This will normally partake in some measure of

4. Goodness.

By way of example, if Crito offers a suitable sacrifice to Asclepius, his sacrifice will be a pious act, in virtue of the form it shares with other such acts. The object of Crito's respectful actions will be the god of healing, who is worthy of devotion as a good and superior benefactor. Insofar as the gods deserve our devotion, they will thus be in the third category, as will a parent. What if the form of the good itself should turn out to be an object of piety? Then what falls under 3) and 4) will coincide. For surely Plato believes that the form of the good is good and worthy of respect.

In the Euthyphro, tò öбıv has the directed structure that we observe in piety. It involves appropriate respect, such as the reverence thought to be due to a parent or

\footnotetext{
${ }^{2}$ Following the Aristotelian mean, Richard Bosley has emphasized to me the importance of sufficiency in understanding moral virtues like piety.

3 Cf. Arist. EN 1096 a15 for an example of this usage: Piety requires us to honor truth above our friends. ('Holiness' here would certainly be a poor rendering of öбıv.) Another suggestive passage is found in On Virtues and Vices, which though spurious echoes Euthyphro $12 \mathrm{c}-\mathrm{d}$ in an interesting way: First among acts of justice come those towards the gods, then those to deified spirits, then those towards one's country and parents, then those towards the departed: amongst these comes piety, which is either a part of justice or an accompaniment of it. (Arist. VV 1250b19-22, J. Solomon tr.).
} 


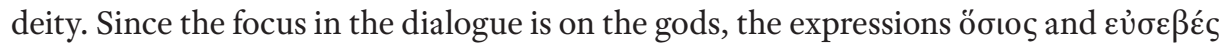
are sometimes used interchangeably. Compare $5 \mathrm{c}-\mathrm{d}$ and $12 \mathrm{e}$, for instance, where Socrates glosses the indictment of ávó a sense of sinful hubris in relation to the gods, and disrespect for what is sacred. The fact that tò ö translate the expression as 'sinlessness', 'righteousness' or 'holiness': words which entail conformity with some moral requirement but do not immediately bring with them an object of respect in the same way that piety does. Nevertheless, although righteousness and piety are not the same thing, if the gods are genuinely good and prefer what is good, our respect towards them may manifest itself in our performing righteous acts. This point leads us into the middle portion of the dialogue and questions about the nature of moral goodness generally, since it seems that moral goodness and divine preference coincide.

In any case, as a consequence of the above considerations about piety we can at once register a way in which divine preferences enter into the moral life on the Socratic view. Piety towards the gods is a moral virtue which involves some deference to them. Assuming that there is in fact something which is divine and worthy of respect - and Socrates never doubts this - pious religious practices will be part of a morally excellent life. Hence we can see already that moral excellence must take account of the gods' preferences in a certain way, insofar as reverence towards someone must take some account of the revered person's preferences. Just as filial piety is a virtue which requires one to do certain things to please one's parents, so religious piety would also require us to do certain things to please the gods. The idea that the gods have preferences and that there are religious obligations to please the gods is not in question in the Socratic dialogues. This is true even though there may be some latent tension between Athenian religious rituals such as sacrifice and Socrates' less anthropomorphic conception of the divine. If the gods enjoy the scent of burnt offerings, for example, then the content of their preferences is not exhausted by their desire that good be done, whatever good may be. Therefore on Socrates' view there is already built into the practice of piety at least one way in which divine preferences affect what counts as morally good.

\section{The Reductio Arguments}

What requires further clarification, however, is what the gods' preferences are, and the ways in which the gods themselves along with their preferences might be subject to moral criticism. What exactly is the relationship between reaching moral excellence and satisfying divine preferences? In their discussion about the nature of piety, both Euthyphro and Socrates assume that the gods wish and command us to do what is morally good. We show respect to the gods by behaving well generally: in addition to being itself a special case of appropriate respect, piety thus requires that we behave in morally excellent ways towards other people. This behavior is both pleasing to the gods and commanded by them. But why is it praiseworthy to perform acts which are commanded by the gods? 
The Socratic discussion comes to be focused on the nature of moral goodness, so that when Socrates asks Euthyphro to clarify what the pious is, he is asking what the moral goodness of those divinely approved acts consists in.

After Socrates quickly dismisses two preliminary attempts to define the pious, Euthyphro is prodded into offering the following formula: "Well, I would say that piety (öбov) is that which all the gods love, and the opposite, what all the gods hate, is impious (ávóбıv)" (Euthphr. 9 e). Socrates responds by drawing two distinctions. First, at

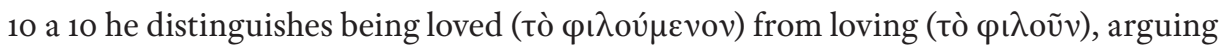
that the former exists because of the latter. In slightly different words, what is being loved,

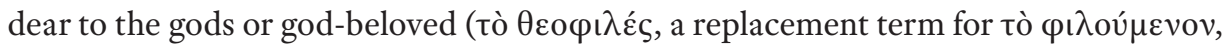
indicating a special case thereof) is so because it is loved, and not vice versa (Euth$p h r .10 \mathrm{~d}$ ). It is harder to express the claim in English than in Greek, but we might call this the priority of acting over being passive, or the priority of acting over being a recipient of action. We can avoid for now the question of just what this priority is supposed to consist in.

Second, Socrates distinguishes a thing's being loved by the gods because it is pious from a thing's being pious because it is loved by the gods (Euthphr. 10 a 1-3, $10 \mathrm{~d}$ 6-7).

The argument now proceeds in the form of two reductios:

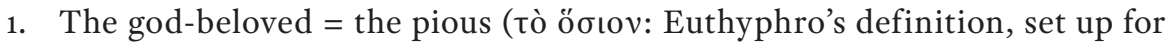
rebuttal).

2. The pious is loved by the gods for no other reason than because it is the pious. (Socrates gets Euthyphro's assent to this at $10 \mathrm{~d}$.)

Hence, by 1 and 2 via substitution of definiens for definiendum:

3. The god-beloved is loved by the gods for no other reason than because it is the god-beloved.

This, however, contradicts the claim that acting is prior to being acted on, as was agreed to earlier. That is, it contradicts:

4. The god-beloved is the god-beloved because it is loved by the gods, and not loved by them because it is the god-beloved (Euthphr. $10 \mathrm{c}, 10 \mathrm{~d}$ ).

And what further follows, by substitution of 'the pious' for 'the god-beloved' in

4. is:

5. The pious is the pious because it is loved by the gods, and not loved by them because it is the pious.

Here Euthyphro is embarrassed to find himself in an inconsistency with his earlier claim. Socrates sums the conclusion of this elenchus up at 11 a:

But now you see that they [namely the god-beloved and the pious] are in opposite cases as being altogether different from each other: the one [sc. the god-beloved] is of a nature to be loved because it is loved, the other [sc. the pious] is loved because it is of a nature to be loved. (Translated after Grube, adding material in brackets.) 
Socrates has pointed out that there are three terms: 1) What the gods love; 2) What

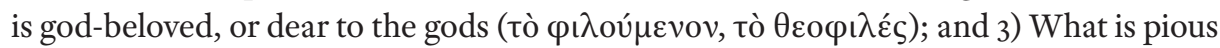
( sentence ' $\mathrm{x}$ is loved because it is $\mathrm{y}$ ' on the supposition that the pious can be defined as the god-beloved. Euthryphro grants that what is pious is loved because it is what is pious. This is not the same as saying that what is god-beloved is loved because it is god-beloved. The former claim is true, the latter false. So, the pious is not the same as the god-beloved.

The argument has been picked over by commentators many times, but disagreement remains about its structure and validity. ${ }^{4}$ One point of contention is whether Socrates is assuming that the substitution of 'the pious' and 'the god-beloved' for one another in this context can be justified. For, if 'because' in ' $x$ is loved because it is $y$ ' reveals a motive for love, then substituting co-referential expressions for one another into the y position will not necessarily preserve the statement's truth value. I will not, however, dwell on the substitution question. Even if the argument is fallacious it contains an important philosophical insight familiar to every student of Plato's early dialogues. We do not need to accept Socrates' puzzling remarks about the priority of active over passive states, nor do we need to settle on a plausible general substitution principle, in order to appreciate the force of Socrates' question to Euthyphro: 'Do the gods love what is pious because it is what is pious?'.

For, if what it is to be good is simply to be loved by the gods, then saying that the gods love the good is not to provide any motive for their love. It is incompatible with explaining that the gods love the good or virtuous thing because they grasp its goodness. Moreover, though Socrates does not stress this point, it fails to account for the fact that calling the gods and their preferences good is to praise, endorse or recommend them. This insight holds true whether we are talking about the imperfect and finite gods of ancient Greek Orphism or an all-powerful and omnibenevolent creator of the universe as in the traditions of Abrahamic monotheism. The same point can also be extended to any proposed definition of what is good as what is loved by a certain individual or social group.

\section{3. 'Because' and the False Dichotomy}

If, however, we look more closely at what Socrates has said, it turns out that he has presented Euthyphro with a false dichotomy and has gained Euthyphro's agreement to an equivocal statement. He offers Euthyphro a false dichotomy at $10 \mathrm{~d}$ when he poses the question: 'Then is it loved because it is pious, but not pious because it is loved?' The question suggests that the two alternatives ('loved by the gods because it is pious' and 'pious because it is loved by the gods') are mutually exclusive as well as jointly exhaustive. Yet it can be true both that something is loved because it is good and that it is good because it is

${ }^{4}$ For discussion of the role that substitution plays, see, e.g. Geach (1966), Cohen (1971), Sharvy (1972) and O’Sullivan (2006). 
loved. The problem is evident in the response which Socrates prompts from Euthyphro: the gods love something for no other reason than that it is pious. On the contrary, it is possible for a good or pious act to depend in various ways for its piety and goodness upon the preferences of the gods, and also for those divine preferences to enter into explanations of why the acts are good or pious. We have already seen one way in which an act may be morally good because it brings pleasure to the gods: a pleasing sacrifice may count as an instance of piety. The 'because' clause here reveals a part of the explanation for love.

The mutually reinforcing relationship between desire, love or preference, on the one hand, and goodness on the other can be explored further through a nonmoral example. Consider a tool, such as a carpenter's hammer. Some hammers are better than others, and the good ones are good because they are sufficient or adequate to satisfy the goals of carpentry. For example, they are of the right weight and strength, well balanced and of a suitable size to be used. A working carpenter will choose and prefer a hammer that is good, rather than one that is bad, and people who share the goals of carpentry will also often choose good hammers because they are good. Ultimately, these goals of carpentry depend on the needs and desires of human beings as expressed in our practices and conventions. If we preferred to sleep outdoors, never used nails, or had a strong aversion to wood we might not have any need for a carpenter's hammer. If we were much weaker or stronger, or had different shaped hands, good hammers might have different characteristics than they do. Therefore, what counts as being a good hammer is determined, at least in part, by the desires, needs and preferences that human beings have.

This does not mean that any person or group of persons make a hammer good by a simple act of the will. Once the goals of carpentry are fixed, no one can simply decide whether a given tool satisfies those goals. It would seem strange to say that anyone has "invented" the goodness of hammers, though someone might have invented the hammer or some of the uses to which it is put. Nor is the goodness of a tool defined in terms of the actual satisfaction of desires. This is because there may be accidental interfering factors which prevent a thing from actually accomplishing its purpose. For example, there may be some problem with the wood or nails which prevents good hammers from being used effectively in a certain case. Or again, a user might just be ignorant of the qualities of a given tool and unwittingly reject it so that it does not actually satisfy his or her desires in spite of its desirability. The good hammer must be adequate, or such as to satisfy the goals in view. But the goals need not actually be realized. ${ }^{5}$

Now consider the question: 'Is a hammer is desirable because it is desired, or is it desired because it is desirable?' Even if 'because' is restricted to motivational explanatory factors, this is a misleading dichotomy inasmuch as the alternatives do not exclude each other. For, a hammer may certainly be desired and chosen by one or more persons on the grounds that it is a good hammer. To repeat, given that it satisfies the requirements of carpentry they have reason to choose the hammer if they share the ends of carpenters. On the other hand, the hammer is desirable because people have the desires that they

\footnotetext{
${ }^{5}$ I am indebted to Richard Bosley here. Compare also a similar account of goodness by F. Sparshott (1970).
} 
have, as manifested in the various practices and conventions of carpentry. We can therefore see how it is both true that a hammer is good because it is such as to satisfy certain preferences and that the hammer is such as to satisfy certain preferences because it is good.

We can imagine a divine command theory of hammers which holds that to call a hammer good is just to say that it pleases the gods. Such a theory is not very plausible, since it is not self-contradictory to say that the gods are pleased by a bad hammer. We also want to say that the gods have a reason to choose or prefer a good hammer, and this reason has to do with the hammer's ability to serve its function. If a divine command theory of hammers were true, the goodness of a hammer would not give the gods any reason to prefer it. Further, the gods would not be praising a hammer by calling it good, but simply expressing a preference, if the divine theory of hammers were true. Thus, such a theory is false. The goodness of a hammer concerns, not only the gods, but the hammer and its capacities to play a role in the institutions of hammer users. It is the hammer's adequacy to serve hammer functions, not its being the bare object of divine preference.

\section{How the Gods Can Help Determine What is Morally Good}

Having considered the case of excellent hammers, let us now return to the case of excellent persons. Moral goodness is harder to theorize about than goodness in hand tools, in part because it requires us to evaluate ourselves for our own objectives. Still, there is some of the same interplay between desire and the desirable, preference and the preferable, love and the lovable. What is loved is loved in part because it is a lovable thing (suitable to be loved): the lover may grasp that the object is of a certain sort capable of prompting love, and there may be a causal story about what the thing does for us. But things are also suitable to be loved in part because of actual love that helps set the standard for lovability. While Socrates has indeed given reason to hold that piety or righteousness is not the same thing as being loved or preferred by the gods, he has not shown that the gods have no control over what counts as morally good or preferable.

The point is that divine power has more than one way to influence what falls within the scope of the pious or righteous. The gods can influence the standards of goodness without making goodness simply a matter of fiat or whim, and they can do this in at least three ways. First, they have an influence on human nature. Second, they have an influence on the environment in which humans live. Third, as prominent members of a moral community to which humans belong they can affect the conventions which give content to many moral judgments. Let us take these in turn.

Although the Greeks did not think of the gods as creators ex nihilo, Greek popular thought often credited the gods along with Prometheus with the creation of humans. Plato's Protagoras (Prt. $320 \mathrm{c}-322 \mathrm{~d}$ ) relates the amusing fable of Prometheus, Epimetheus and Zeus allocating abilities to humankind. The nature and qualities which are assigned to human beings clearly enter into what constitutes the best life for us. Thus, the fact that we are social creatures gives rise to community life and the need to practice 
social virtues such as justice, generosity, and friendliness. The fact that we reproduce ourselves and have children who are helpless at a young age is another contingent but important fact about us. There would be no virtues of filial piety or good parenthood if there were no such thing as parents and children. By helping determine the natures, powers and needs of humans, the gods help to determine what sorts of behavior count as praiseworthy in humans.

Similarly, by influencing the natural environment the gods can influence what qualities in humans are adequate for praise and blame. For instance, if the universe were a much easier place in which to make a living, certain types of fortitude, ambition and diligence might become less important than they are. This is a second respect in which the gods might help to determine what is morally praiseworthy.

There is also a third respect in which the gods play a role in the moral life of humans. Namely, the gods are often thought to interact with humans in such a way that they form part of an extended moral community. According to much religious tradition they are affected by human acts at least insofar as they take pleasure in being acknowledged by human beings and resent being slighted. They approve or disapprove of individual actions. They make moral judgments about people and are themselves the subjects of moral judgments. Further, various Greek myths describe situations in which the gods act directly upon humans by granting them benefits, having sexual relations with them, protecting their favorites in battle or by sending storms to sink the ships of those whom they dislike. (Hesiod and Homer, for instance, are full of such stories.)

It is true that Socrates has a less anthropomorphic view of the gods than some of his fellow Athenians do. We saw his skepticism about the myths which attribute disreputable human behavior to the gods (Euthphr. $5 \mathrm{e}-6 \mathrm{c}$ ). He seems doubtful whether the gods could have need of human services (Euthphr. 14 e - 15 a). However, in the Socratic dialogues he also makes many references to his desire to follow the divine will, e.g. his pursuing his function as a gadfly in response to the Delphic oracle, his obedience to the voice which is his personal divine sign, his closing advice in the Crito to follow the way in which the gods are leading, etc. So Socrates appears to have a lively sense that the gods reveal themselves to human beings in some way and have certain substantive desires or preferences for human behavior.

Members of a moral community, whether human or divine, develop certain conventions which give content to moral standards. On a very mundane human level, take generosity in tipping, for example. What counts as a suitably generous tip in a restaurant (say) depends in part on what customs exist at a certain time and place. Giving far more than the conventional amount would risk extravagance or showiness, or it might reveal too much eagerness to ingratiate oneself. Giving far less would risk meanness or rudeness. There is no way to deduce the right amount from first principles; knowledge of convention and experience of social relations is the only guide. Because of their knowledge and power the gods are sometimes treated as unusually prominent citizens of the moral commonwealth. In their preferences for human behavior and the expression of their will they help to set the conventions which fill moral standards with content. For example, it 
has often been thought that the gods take an interest in establishing and preserving the conventions of marriage and sexual propriety and modesty in dress.

If the gods have a power to create or alter human nature, if they intervene in human affairs, if they are members of a moral community, they would have a significant role in determining the content of moral judgments. What is good or pious is so in part because the gods' preferences help fix what is good, while knowing that this individual act meets the standard for goodness, the gods also have a reason to prefer it. But now, suppose that there are no gods after all, or that their preferences are unknowable. Much of what has been said above still applies with respect to purely human preferences. The conventions and practices that bear on human behavior will have to be established by human beings. Goodness will not be decided simply by fiat, nor "invented" either, but the fact that an act is of a sort that is desired by people will be a factor contributing to its real excellence. Once again, one cannot directly infer that a thing is desirable from the fact that it is desired by someone, but being desirable is not entirely independent of what is actually desired by human beings. A particular act can be good, in part because it is loved by people and also loved by people for the reason that it is good. Yet it will not be contradictory to say that a lovable or desirable thing is not actually desired, since there is always the possibility of an interfering factor such as ignorance or some other accidental defect. Thus, room is left for error in moral judgment.

\section{Concluding Remarks}

One way to read the Euthyphro is to see Socrates as approaching a distinction between value laden expressions such as 'pious', 'good', 'lovable' or 'desirable' and non value laden expressions such as 'loved' or 'desired', and as showing that the former cannot be defined in terms of the latter. We should be wary of expressing matters this way. Nevertheless, the divine command theory of goodness is false, since it fails to account for the fact that to call something good is to praise and recommend it.

Assume in company with Socrates that there are gods who have an influence on human affairs and act as members of a wider moral community. As we have seen, the dilemma which he poses to Euthyphro (pious because loved by the gods, or loved by the gods because pious) does not offer two mutually exclusive alternatives. It should now be clear that there are various ways for the preferences of such gods to help determine which acts are adequate for moral praise or blame. It could therefore hardly be the case that religious doctrines, if true, are irrelevant to the content of morality. Knowledge of the gods' preferences, if such knowledge were available, would be of importance to moral theory for the reasons pointed out. Nor does Socrates claim otherwise in the Euthyphro.

Those of us who do not worship the Greek gods, and who may indeed not worship any gods at all, can still draw some insight from the Euthyphro. It stimulates reflection about the ways in which human preferences determine what behavior is morally excellent and the ways in which they do not. 


\section{BIBLIOGRAPHY}

Cohen, S. M., 1971, 'Socrates on the Definition of Piety: Euthyphro 10A-11B', JHPh 9, pp. 1-13.

GEACH, P. T., 1966, 'Plato's Euthyphro: An Analysis and Commentary,' The Monist 50, pp. 369-382.

O’Sullivan, B., 2006, 'The Euthyphro Argument (9d-11b)', SJPh 44, pp. 657-675.

Sharvy, R., 1972, 'Euthyphro 9d-11b: Analysis and Definition in Plato and Others', Nous 6, pp. 119-137.

SPARshotт, F., 1970, 'Disputed Evaluations', APhQ7, pp. 131-142.

GLEN KOEH N

/London, Canada /

\section{Divine Command and Socratic Piety in the Euthyphro}

While Socrates was in his own way a deeply religious man, the Euthyphro is often thought to provide a refutation of the divine command theory of morality: the theory that what is morally good is good because it is divinely approved. Socrates seems to suggest that what is holy or pious (öбเo૬) is pleasing to the gods because it is holy, and not holy because it pleases them. Thus the dialogue is sometimes presented as showing that what is morally good and bad must be independent of the divine will. I argue that matters are not so simple, since there are several ways in which the gods could help determine which acts are good, for instance, by disposing certain human affairs which are relevant to moral decisions. Moreover, Socrates suggests that he has obligations to the gods themselves, and these obligations would have to depend in part on what pleases them. It follows that the dilemma which Socrates poses to Euthyphro (pious because loved by the gods, or loved by the gods because pious) does not offer two mutually exclusive alternatives. There are various ways for the preferences of such gods to help determine which acts are adequate for moral praise or blame. It could therefore hardly be the case that religious doctrines, if true, are irrelevant to the content of morality. Knowledge of the gods' preferences, if such knowledge were available, would be of importance to moral theory. Socrates himself does not deny this, nor should we.

Socrates, Euthyphro, piety, the divine command theory of morality
K E Y W R D S 